\title{
NATO in Europe: Between Weak European Allies and Strong Influence of Russian Federation
}

Lidija Čehulić Vukadinović, Monika Begović, Luka Jušić

\section{Abstract}

After the collapse of the bipolar international order, NATO has been focused on its desire to eradicate Cold War divisions and to build good relations with Russia. However, the security environment, especially in Europe, is still dramatically changing. The NATO Warsaw Summit was focused especially on NATO's deteriorated relations with Russia that affect Europe's security. At the same time, it looked at bolstering deterrence and defence due to many concerns coming from eastern European allies about Russia's new attitude in international relations. The Allies agreed that a dialogue with Russia rebuilding mutual trust needs to start. In the times when Europe faces major crisis from its southern and south-eastern neighbourhood - Western Balkan countries, Syria, Libya and Iraq - and other threats, such as terrorism, coming from the so-called Islamic State, causing migration crises, it is necessary to calm down relations with Russia. The article brings out the main purpose of NATO in a transformed world, with the accent on Europe, that is constantly developing new security conditions while tackling new challenges and threats.

\section{KEY WORDS:}

NATO, EU, Russia, security and stability 
The NATO summit in Warsaw, the second meeting on a high level since the Russian annexation of Crimea in 2014, represents a cornerstone in the adaptation of the alliance to that new complex security scenario in international relations. NATO's essential mission has stayed the same: to ensure that the alliance remains a community of freedom, peace, security and shared values, including individual liberty, human rights, democracy and the rule of law, with the accent on Europe keeping transatlantic ties strong and important for NATO's global role. The alliance will continue effectively fulfilling all three core tasks as set out in its Strategic Concept agreed at the summit in Lisbon in 2010: collective defence, crisis management and cooperative security. These tasks remain fully relevant and complementary, and contribute to safeguarding the freedom and security of all NATO members. In Warsaw, NATO focused strongly on the mutual commitment to defend the territorial integrity and sovereignty of all its members, while deterring attacks with its full range of capabilities, including nuclear ones (Corvaja 2016: 5).

Although it could be noted that in the development of all main theories of international relations (neorealism, liberal institutionalism and social constructivism) after the end of the Cold War it was predicted that NATO would cease to exist after the bipolar world collapsed, as its purpose of defending the Western world and Europe against threats coming from the East would not be needed any more, NATO went through a transformation and showed its new purpose in a changed world. NATO was no longer regarded only as an alliance and, as neorealists claim, if this transformation never happened, the alliance would have no purpose without the opposite side. By adjusting to the national interests of the member states, it attracts new countries to become members and justifies its role of transformed alliance.'

Defending the territorial integrity and sovereignty of all its members

1 The neorealist perspective of NATO's transformation and reasons for it are presented in Waltz (1993, 2000). International institutions adjust to the needs of the states and their national interests, sO NATO stopped being an ordinary alliance. On the definition of the alliance, see more in Walt (1997). 
became again, in the new context, one of the main tasks of a transformed NATO. Together with recently aggravated relations with Russia, ongoing instabilities in the Middle East and new challenges in the Western Balkans, NATO is again met with new challenges and is at the crossroads of further adapting its enlargement policy, while Europe is facing a major refugee crisis, a crisis in Ukraine that started with Russian military intervention in Crimea, the rise of radical Islam and terrorism, constant instabilities in the Western Balkans, an accelerating proliferation of weapons of mass destruction and missile technology, the growing threat of cyberattacks, climate change, risks of disruption to energy supplies, more and more unemployed and poor people, all kinds of international criminal activities, etc. All of these 'obstacles' are today challenging Euro-Atlantic security and the international order.

The persistence of NATO after the Cold War was very important for Euro-Atlantic stability and security, and Waltz, as a neorealist, sees it as a possibility for allies to control each other in many ways, while having collective defence as a main task that still specifies NATO as an alliance. ${ }^{2}$ This essay will bring out the reasons Europe needs NATO, despite its creation of the Common Security and Defence Policy. While tackling the main research question, the theory of neorealism will be used in describing how NATO is transforming, especially in regard to decisions reached during the Warsaw Summit, where it began to be clear that defence and deterrence are the bedrock of NATO and an indispensable foundation for any activities undertaken by NATO.

The research concentrates on presenting a perspective of NATO from the view of Euro-Atlantic security, highlighting the importance of cooperation among members and partner states. The essay will show an inevitable role of NATO in the perseverance of European security, due to new threats and challenges, from the perspective of the conclusions and decisions reached at the Warsaw Summit.

2 It can be said, looking from the perspective of neorealism, that states join alliances to ensure the behaviour of other allies, advancing the interests of their foreign policy and trying to reduce the uncertainty of the international system, which neorealists define as international anarchy. Neorealists see states and great powers as central to world politics, characterized as anarchy, which additionally causes them to be within an alliance (Waltz 1979; Waltz 1993: 44-79). 

framework

\section{Theoretical framework}

There is a distinction between alliances as a response to power and as a response to threat, according to neorealists. If we look at how Stephen Walt explains it, we can see that the distribution of power is an extremely important factor, and "the level of threat is affected by geographic proximity, offensive capabilities, and perceived intentions" (Walt 1997: 5). Looking from this perspective, it could be noted that new Russia poses more of a threat than a power, so with the new security environment in the contemporary international community in mind, NATO's strategy presented in Warsaw was mainly directed towards Russia's action in Crimea and what kind of a threat it presents. There is a suggestion by Glen Snyder that "alliances cannot be understood apart from their context in the international system" (Snyder 1997: 16). The nature of NATO, therefore, varies with the changes that occur in the international arena, and with the new role of Russia, global security and stability goes through a shifting of power. Multipolarity is described with a lack of clarity in international politics, and NATO stands to reduce the uncertainty; however, in the absence of a single point of danger, "alliance collapse is a far more imminent possibility" (Snyder 1990: 121) The reason for NATO's survival is that the alliance has managed to stay relevant as a tool for managing modern conflicts while being open and inclusive, not only for new members, but also for different kinds of partnership.

When entering an alliance, states may either balance (ally in opposition to the principal source of danger) or bandwagon (ally with the state that poses the major threat) (Walt 1985: 4). Balancing is alignment with the weaker side; bandwagoning means to choose the stronger. Walt's conclusion is that the threat determines the choice of ally and how long the alliance will last. The balance of threat theory is based on balancing behaviour and the proposition that states will join alliances in order to avoid domination by stronger powers. States join alliances to protect themselves from states or coalitions whose superior resources could pose 
a threat (Walt 1985: 5). That is what Walt offers as the reason that NATO has begun transformation, having the goal to position itself strongly in the international order. Neorealism offers an insight into reasons why states choose to be under the NATO umbrella, as it offers them a possibility to achieve their goals and feel safe in the international arena.

The Warsaw Summit was a summit that showed the need for a high level of unity among member states. It showed the importance of a Euro-Atlantic partnership that becomes real through NATO and brings the anarchy in the international arena more under control. NATO, as an intergovernmental organization with a core competence of security, has developed additional diverse institutions for conducting its actions. Therefore, NATO is always more than just an alliance, but primarily an alliance. The European Union has developed a defence dimension, with military forces as part of its Common Foreign and Security Policy and Common Security and Defence Policy, but its process in building a common military force, or 'EU Army', has been rather too slow to guarantee security and stability on the old continent.

\section{Warsaw Summit in decisions}

There is an arc of insecurity and instability along NATO's periphery (challenges and threats originate both from the eastern and the southern flanks of NATO) and beyond, sO NATO's Warsaw Summit offered a vision of the future of the alliance in 3D: deterrence, defence and dialogue (Luciolli 2016: 21). NATO decided in Warsaw to establish an enhanced forward presence in its eastern flank (Baltic, Poland) to demonstrate its determination, solidarity and ability to act by triggering an immediate allied response to any aggression. Beginning in early 2017, an enhanced forward presence will comprise a multinational force provided by framework nations (USA, Canada, Germany and the United Kingdom) and other contributing allies on a voluntary, sustainable and rotational basis. They will be based on four battalion-sized battle groups. At the same time, after the Warsaw Summit, the alliance should remain open for dialogue even with those who do not share the Euro-Atlantic democratic norms and 
values. NATO should develop cooperative arrangements (with both state and non-state actors) with all partners willing to work and cooperate with the alliance. In response to asymmetrical and non-military threats, NATO should offer its unique capabilities and experience to other organizations or formats that may be better suited to solve multi-dimensional crises.

Besides all the other challenges to stability and security in the contemporary world, the Russian Federation is seen by NATO as the main destabiliser of the European security architecture. The international community should not have been surprised by Russian action in Crimea and its subsequent influence in Donbas, eastern Ukraine. The December 2014 Military Doctrine and the December 2015 National Security Strategy of the Russian Federation state that Russia sees the United States and NATO as adversaries and Russia as the leader of a new anti-NATO alliance in a multipolar world. In Ukraine, the Russian Federation used military force and other forms of warfare to acquire territory, decisively breaking international law and reneging on its commitment to international agreements. Russia's action rang alarm bells in those NATO members who border the Russian Federation. The main publicly declared pretext for Russia's actions in Ukraine and Crimea was protection of a Russian-speaking minority in those regions. Some NATO members are now afraid that such behaviour might be used as a pretext for further Russian action against some other countries among its neighbours (Baltic states, Poland), because Moscow has made no secret of its belief that its neighbours should be firmly within its sphere of influence (Hill and Gaddy 2013: 312-314). Thus, the Russian annexation of Crimea effectively ended a 25-year effort by NATO to build a strategic partnership ${ }^{3}$ with that country (Čehulić Vukadinović 2010: 190-210).

Also, this was a showcase for Russia's new hybrid warfare tactics. ${ }^{4}$ Russia's

3 In 1991, NATO established the North Atlantic Cooperation Council (NACC) as a forum for dialogue and cooperation with former members of the Warsaw Pact. In May 1997, the NATO-Russia Founding Act, the landmark document which laid the foundation of the post-Cold War NATO-Russia relationship, was signed. That document affirmed the shared commitment of both parties to build a stable, peaceful and undivided Europe, whole and free, for the benefit of all its people. In 2002, the NATO-Russia Council was established. This is a joint decision-making body bringing together the 28 allies and Russia. NATO even went so far as to suggest that Russia could have a role in supporting the missile defence system put in place to defend allies against a potential ballistic missile attack from the Middle East (Turner 2016: 8).

4 Russian General Valery Garasimov, Chief of the General Staff, described in February 2013 the new Russian hybrid warfare techniques, stating that "the very rules of war have changed. The role of non-military means of achieving political and strategic goals has gone, in many cases, they have exceeded the power of force of weapons in their effectiveness. The focus of applied methods of conflict has altered in the direction of the broad use of political, economic, informational, humanitarian and other non-military measures, applied in coordination with the protest potential of the population. All this is supplemented by military means of a concealed character, including carrying out actions of informational conflict and the action of special operations forces. The open use of force, often under the guise of peacekeeping and crisis regulation, is resorted to only at a certain stage, primarily for the achievement of final success in the conflict" (Gerasimov 2013: 2). 
rhetoric against NATO, including threats of a nuclear attack, is backed by Russia conducting both ground military exercises and air activities close to the borders of some NATO members. Furthermore, Moscow has accelerated the deployment of conventional capabilities along NATO's borders. Deployment of Russia's air defence system, coastal defence system and anti-access area denial (A2/D2) capabilities in Kaliningrad and Crimea have the aim of intimidating the alliance and turning the balance of forces to Moscow's advantage. Also, any ground reinforcement would have to transit through the narrow land corridor of Suwalki linking Poland and Lithuania between Kaliningrad and Belarus. For all those reasons, NATO member states bordering the Russian Federation with a substantial ethnic Russian population feel very vulnerable, especially in the case of a Russian military attack on one of the eastern NATO allies (Andzans 2016: 14-20). The new democracies in central and eastern Europe were invited to join the alliance but Article 5 security guarantees were not supported by the new NATO command and force structure necessary to secure the defence of these new NATO members. Russian capabilities, patterns of behaviour and political-military messaging make it clear that Russia perceives the post-Soviet space as its sphere of influence, wants to maintain a buffer zone extending into European Union and NATO territory, and is attempting to enforce the creation of a new security architecture that would allow it to weigh in on the defence and security choices of sovereign states. For Russia, the best way to achieve this could be by undermining the credibility of the alliance, making it irrelevant as a collective defence organization. This would represent a significant strategic victory for the Russian Federation (Lorenz 2016: 10).

There is no doubt that the extraordinary engagement and commitment of the United States is crucial for Euro-Atlantic and European security. However, at the Warsaw Summit, real progress in cooperation between NATO and the European Union was achieved. The joint declaration (NATO $2016 \mathrm{~b})$ signifies that NATO and the European Union should work closely to address security challenges such as the migration crisis, terrorism, hybrid threats, cyber defence or energy security. But do the Europeans have a united political voice? Or, more importantly, are they capable of fulfilling such tasks together with the United States and Canada? The European Union is still facing the consequences of its institutional, financial and migrant crises (Fata 2011:33-39) and, with the rise of populism, isolationism 
and extremism, the majority of members are not willing to increase the defence budget. Besides the external threats (Russia the main one), NATO is facing many internal challenges today, mostly connected with its European member states or its relations with the European Union. The very popular trend of building an EU Army, which would lead to greater autonomy of the European Union in defence matters, is proving insufficient for European security and stability: "Military operations will occur in ad hoc coalitions that rely on both NATO and EU means, thus resulting in a type of institutional interdependence, but US superiority and European weakness will in the context of coercion create a new type of military dependency" (Rynning 2002).

\section{Russian influence on NATO's Eastern members}

The July 2016 Warsaw Summit marked a turbulent time for NATO. Eastern members of NATO, led by Poland, were calling upon NATO to bring a bigger armed presence to their countries. After long and difficult negotiations, the member states concluded that a bigger military presence in Poland and the Baltic states was needed and that four multinational brigades would be sent to those countries under the command of officers from the USA, Great Britain, Germany and Canada. Also, NATO would continue to build its anti-rocket shield in Romania and increase the presence of NATO navies in the Black Sea (Public Diplomacy Division 2016: 1). The goal of these measures is to let the Russian Federation know that any further unilateral decisions made by Russia (such as in Ukraine) will not be tolerated, which is also a message of support to the Eastern European member states.

The Warsaw Summit had the aim of showing Russia that a homogeneous group of alliance members was determined to maintain liberal democracy and human rights. The same group equally condemned the unilateral actions of the Russian Federation in Ukraine and would condemn Russian actions in Syria. However, the Russian Federation, with its diplomatic channels, managed to make a division between some member states and NATO: if this situation persists, some of them could 
become advocates for its policies within NATO. Countries like Hungary have traditionally had turbulent relations with Russia, but those relations have significantly improved in the last decade due to economic ties and dependence on Russian oil and gas, and because of a dependence on Russian military equipment. On the other side, there is Poland, regarded as the forefront of the anti-Russian bloc in NATO, and the challenges arising from within. Some experts in international relations say that if Poland continues to feel marginalized and unsafe, it could even spark its turning to the Russian Federation. Russia has increased its military spending, ${ }^{5}$ further developed its missile and nuclear arsenal, ${ }^{6}$ and holds military exercises in the neighbourhood of NATO member states. That could be defined as an outward challenge and could explain the convergence of these countries in the past few years, especially in the case of Hungary, as a new friend of the Russian Federation.

The Russian military started its process of modernization and reformation in 2012 with a complete overhaul of its doctrine, which gave birth to a new armed force. Until then, Russia had held the doctrine from the former Soviet military which had defined its armed forces as a "mass army based on a general draft" (Kacprzyk 2016: 10), and that doctrine shifted towards a modern and professional armed force. Russia has also transferred the majority of its armed forces to the European part of Russia, or more precisely to its Western military district which is located on the border with four NATO member states. The importance of this district can also be seen in the decision made by Russian joint staff to give this district top priority in education, equipment and modernization (Kacprzyk 2016: 10). Russia has also completed the integration of Belarus in its Air and Missile Defence System, and with that it has completed its goal to create a solid front towards NATO (Kacprzyk 2016: 10). Another big issue for the Baltic states and Poland is the region of Kaliningrad, ${ }^{7}$ which is considered to be the most militarized region in Europe. A new problem emerged when the $152^{\text {nd }}$ Missile Brigade was transferred to the town of Chernyakhobsk in Kaliningrad Oblast. The brigade is armed with the newest Iskander

5 The Russian military budget has been rising since the start of the modernization and reformation of its military. The 2015 budget was 54.5 billion US dollars and the 2016 stands at 49.2 billion US dollars, which makes it one of the highest in the world. For more, see Chance (2016).

6 Russia has developed the world's most formidable nuclear missile, Satan 2. For more, see Shukla and Smith-Spark (2016).

$7 \quad$ Kaliningrad Oblast is a Russian enclave located between Poland and Lithuania. It is of very high strategic value for Russia, because it is located between NATO member states and missiles in that region can successfully target NATO member states in that region. 
missiles which can effectively hit targets in the Baltic states and in Poland ${ }^{8}$ (Kacprzyk 2016: 11).

At the moment, there is no imminent threat of conflict between Russia and NATO, but the military exercises which were conducted in Western Russia, such as Union Shield, Ladoga and West, have had the goal of rapid deployment and transportation of troops across the Western district. These exercises have shown a high level of readiness within the Russian armed forces and should be seen as a provocation towards the alliance (Kacprzyk 2016: 11). The countries that are closest to Russia are already viewing it as such, so Lithuania, Estonia and Latvia, for example, are going to triple their military budget in fear of a Russian attack. ${ }^{9}$ Russian President Putin is opposing NATO enlargement to the east and, with invasions in Ukraine and Georgia, where Russia created disputed territories (South Ossetia, Abkhazia, Crimea), Putin made it clear that no country will join NATO. These two countries were very close to getting a Membership Action Plan for their membership in 2008, but Russia clearly opposed this and proceeded to invade them. "Putin now has the most favorable international environment since the end of the Cold War to continue Russian expansion. European unity is fractured. Alliance members are questioning the value of the mutual security pact. And the next American president seems openly favorable to Russia and ready to excuse Russia's irresponsible behavior" (Miller 2016). The Times (22 Nov 2016) reported that Putin is moving his missiles to its western European enclave as a threat to Europe, which shows that the Baltic states have a special place in Russian foreign policy. Lithuania has already introduced compulsory military conscription, concerned about the geopolitical environment and its proximity to Kaliningrad.

Feeling threatened, Poland still believes that it is not getting enough help from NATO for protection against a possible Russian attack. Poland has a very interesting internal and external political situation. If we take a closer look to the internal political factors, Poland is a liberal democracy that has entered into a phase of crisis. The crisis began last year when parliamentary elections were won by the coalition led by the Law and Justice and

8 The full range of the Iskander missile system is $700 \mathrm{~km}$. From Kaliningrad Oblast, it can effectively target even Berlin. For more, see BBC (2016).

9 In 2020, the combined military budget of Lithuania, Estonia and Latvia will be an estimated 2.1 billion US dollars, which is double the value in 2004 . For more, see Reuters (2016). 
Civic Platform. Their win saw a major shift in Polish politics from liberal to conservative, which criticizes the foundation of liberal democracy. Polish President Jaroslaw Kaczynski openly claimed in his speeches that Poland should dismiss the weight of liberal democracy and that it must pave its own way (Buras and Balcer 2016). The external political situation of Poland is conditioned by its environment. Since its democratic transition, Poland has positioned itself as a leader of the anti-Russian coalition in Eastern Europe, and it holds this role until today. Because of fear of a Russian invasion, Poland is one of the few countries in the region that had its army completely modernized and reformed according to current NATO standards (ibid.). Similarly, Poland's external political situation is affected by the situation in the region, where it borders Ukraine. Until 2014, Poland had a stable economic partner in Ukraine, but since the beginning of the aggression Ukraine has no capacity to be Poland's partner. With the victory of the coalition of the Party of Law and Justice and Civic Platform, Polish official rhetoric became markedly anti-Western and anti-European (ibid.).

Poland would be affected the most were we to see a continuation of an aggressive Russian foreign policy. Also, we can notice a similarity between the two countries. Putin continues to use the uncertain domestic and foreign situation as an excuse to tighten the grip on his people, and in the past year the Polish political elite has started doing the same thing. Russia's aggressive foreign policy has strengthened the anti-democratic forces within Poland and, if not dealt with properly, this situation will only continue to deteriorate (ibid.).

These political developments are extremely problematic for Poland, and if these problems are not resolved, NATO could face a new situation if Poland chooses to depart from NATO. The alliance has so far had a faithful and stable partner in Poland, but Poland is starting to feel more and more marginalized and ignored by Brussels. Poland feels that not all NATO member states realize its situation, as the focus is Mediterranean member states with Syria and the refugee crisis. NATO must find a way to return a sense of security and sense of importance within the alliance to Poland, because at this point further cooling of relations between Brussels and Warsaw would only go in favour of the Russian Federation. 
Another Eastern European country that worries the NATO administration is Hungary. It maintains excellent political relations with Russia and traditionally leans economically to the East and the Russian Federation. Hungarian turning to Russia began in 2010, when Fidesz rose to power in Hungary and Viktor Orban became the new Prime Minister. One of his first official visits to a foreign country was a visit to Russia in November of the same year (Hegedus 2016: 1). Before the sanctions against the Russian Federation were imposed, imports from Russia amounted to 6.89 per cent of total imports to Hungary. This may seem a small figure, but this percentage includes most Hungarian gas, oil and other fuel imports, and comprises an important part of its economy (ibidem.). From this arose the first fear that Hungary could fall under Russian influence, if Russia were to threaten Hungary with higher gas prices. ${ }^{10}$ NATO leaders were worried that this price could be the result of an agreement according to which the Hungarians will protect Russian interests within the alliance, but at the time of the adoption of sanctions against Russia, the Hungarians did not veto the decision (ibidem.). However, the suspicion and fear that the Hungarians might veto the decision is actually Orban's favour to Putin, because it has been shown that the Russians can influence a country that is a member of NATO.

A new, far heavier worsening of relations between Hungary and the countries in the NATO alliance, and between Hungary and other countries of the Visegrad Group, happened at the very beginning of the Ukrainian crisis when Orban called for the establishment of the autonomous region of Transcarpathia in Ukraine. In this historical region, Hungarians form a large minority and this statement was interpreted as an attempt to destabilize Ukraine and attempt to further tear apart Western allies, leading to the short-term isolation of Hungary from its neighbours (ibid.).

Author Daniel Hegedus called Hungarian foreign policy a "peacock dance" (ibidem.) in which Hungary took two steps forward and then one back. An example of this is when Hungary introduced sanctions to the Russian Federation and accepted an agreement made at the NATO summit in Cardiff in 2015, but subsequently stopped the return of gas to Ukraine (ibidem.). This influence does not stop only at Fidesz, but

10 That would not be possible, because Gazprom and the Hungarian government have signed a contract that 
is probably a lot stronger in the Hungarian ultra-right party Jobbik. Jobbik has become the third political option in the country in the past few years and, unlike Fidesz, which is connected to Moscow by certain dirty jobs, "1 Jobbik is directly funded by the Kremlin (ibid.). But their connection does not stop there. Jobbik representative in the European Parliament, Bela Kovacs, finished college in Moscow at MGIMO University in 1986 and lived in Moscow until 2003. In 2010, Bela Kovacs became Jobbik's representative in the European Parliament, and in 2014 he was accused of espionage for the Russian Federation by the Hungarian high state prosecutor; however, the case never came to trial because of his immunity as an MEP (ibidem.).

\section{NATO alliance and new relations with the European Union}

Many European and transatlantic NATO allies have become rather nervous over the new Russian role in international security, and NATO has started to insist upon and ask its European allies for a harsher tone in communications with Russia. However, Europeans still hesitate in sending Russia robust responses or harsh messages, especially given that the strongest EU member state is about to leave the Union - Great Britain after Brexit - but also being aware of the status of European defence capabilities.

The NATO summit in Warsaw was also, in a way, a reminder of Western sanctions against Russia; however, Germany showed no firm position on the strategy towards Russia or on NATO's presence in the Baltics and Poland, which very clearly showed how German politicians, especially Angela Merkel, are very cautious about the stand on Russia. According to a survey conducted by the Körber Foundation in March 2016,12 81 per cent of Germans favour closer ties with Russia and see Russia as an equal power with a rich culture and history. This kind of position towards Russia among Germans is also driven by economic interest, especially in relation

11 We can see these connections in three jobs in particular: the Paks nuclear power plant, the MET gas supply scheme and the modernization of the subway cars on Budapest underground line 3.

12 The survey was conducted among 1,000 individuals in Germany and 1,024 in Russia (Körber Stiftung Survey 2016). 
to gas pipelines. With better business ties between Russia and Germany, German politicians could have in mind that they will contribute to lessen the threat Moscow poses, and therefore are very mild towards Russia. In a 'Frayed Partnership' survey (2016) carried out by the German Bertelsmann Foundation and the Polish Institute for Public Affairs' ${ }^{13}$, a high percentage of Germans - 57 per cent — replied 'no' to the question should German soldiers stand in defence of NATO members Poland and the Baltic states if they are attacked by Russia, and 49 per cent of respondents do not believe that a permanent NATO military presence will increase their sense of security and therefore NATO should not create permanent bases in Eastern Europe and the Baltic states. These perceptions have security implications, especially for NATO, because the eastern alliance (Poland and Baltic states) wants NATO to do more to defend them, feeling threatened by Russia. For European security and unity of allies within NATO, it is very important how Germany perceives Russia, but also how it perceives NATO and its role within the alliance.

The Warsaw Summit was also characterized by NATO officials trying to seek confirmation on continued unity among allies concerned about a postBrexit European Union, while Great Britain has one of the alliance's most capable militaries in Europe. Even countries that are not NATO members, such as Sweden, were and are concerned over Russian behaviour and would like to strengthen ties with NATO. "At this point of time we cannot afford to disagree on defence concerns," said Swedish Defence Minister Peter Hultqvis during the Summit (Champion 2016). If Britain really leaves the European Union, it loses the influence it has had so far within the Union, and that could be a trigger for Britain to become more committed to the alliance. Losing one of the strongest military powers within the European Union could be dangerous for the rise of populist parties that very often aim at the rebirth of nationalism. Without a united Europe, not only could Russia present a problem, but Germany, too. Alan Posener in The Guardian thinks that Brexit is irresponsible and that the European Union, as well as liberal Germans, needs Britain (Posener 2016). Different crises are striking Europe, especially economic and migrant crises, but also a fear of terrorism, so there is a trend for right-wing populists to gain greater power in European countries such as Austria, Finland, Hungary, Latvia, Lithuania, Norway, even Germany and Great Britain with UKIP,

13 'Frayed Partnership' German public opinion on Russia (2016) gives an overview of reasons of declining GermanRussian relations since 2014. 
presenting challenges both to European democracies and to the process of European integration, which results in growing scepticism towards the EU. ${ }^{14}$ The rise of populist parties is dangerous for further integration of the EU and for its enlargement process, as they reject what the EU stands for and how it works. European values such as human rights, rule of law, human dignity, freedom, democracy and equality, which are shared by the NATO alliance, should not be given up on, as that would weaken the EU's credibility, and endanger transatlantic ties. Referring to the utility of being a NATO member state and a partner country, Edström, Matlary and Petersson (2011) claim that a fundamental question is whether the utility of the partnerships is mutual, and if not, that is a problem. The answer seems to be that the partners seem to gain more utility from NATO than NATO gains from its partners. Only a united and unfractured Europe can be a security guarantor. During this fragile time for European unity, Russia is testing the transatlantic alliance, and the strongest EU ally, the United Kingdom, by enforcing Brexit, will lose the opportunity to have an influence from within, therefore making Europe more divided. "Without Britain, there won't be anybody in the EU to defend sanctions against us so zealously," wrote Sergey Sobyanin, the Mayor of Moscow, on Twitter in relation to Foreign Policy (De Luce and McLeary 2016).

It seems that Brexit contributed to fracturing the European Union and endangered the transatlantic community's future of staying united. After the Presidential elections in the US, it is a question of what will be the future role of America, which has the most important position in NATO and which contributes most to the NATO alliance budget. After the win of Donald Trump, the world, and especially Europe, became worried about the US leaving the alliance. NATO General Secretary Jens Stoltenberg said that the West faces its greatest security challenges in a generation, and that 'going it alone' is not an option for Europe or the United States (Stoltenberg 2016). One problem that the alliance faces is the budget, considering that the US currently contributes almost 70 per cent of NATO spending. Although it is in the utmost strategic interest of the US to have a stable and secure Europe, it could happen, with Trump as American President and his announcements, that the US reduces its financial contribution to NATO, which could make some European countries more fragile in the

14 What is undeniably happening, however, is that the continent's traditional mainstream parties are in full retreat. Across Europe, the centre-left social democrats and centre-right Christian democrats who have dominated national politics for 60 years are in decline. For more on this issue, see Goodwin (2011), Bröning (2016) and Henley et al. (2016). 
$\Omega$ face of new threats and create unstable new relations in the international order. "It is all too easy to take the freedoms, security and prosperity we enjoy for granted. In these uncertain times we need strong American leadership, and we need Europeans to shoulder their fair share of the burden", said Stoltenberg in Britain's Observer newspaper (Stoltenberg 2016). Stoltenberg also expressed his concern over Trump's admiration for Russian President Vladimir Putin, who wants Russia to withdraw its forces from Russia's borders. In such a constellation of new conditions, the European Union also faces challenges coming from within.

Almost ten years ago, NATO member countries agreed to commit a minimum of two per cent of their gross domestic product (GDP) to spending on defence. This guideline principally serves as an indicator of a country's political will to contribute to the alliance's common defence efforts. However, even some of the rich EU countries, like Germany as the biggest EU economy, spend less than two per cent of their GDP on defence (for more on defence expenditure, see www.nato.int or www. worldbank.org). 
Table 1: NATO military expenditure as percentage of GDP in 2016

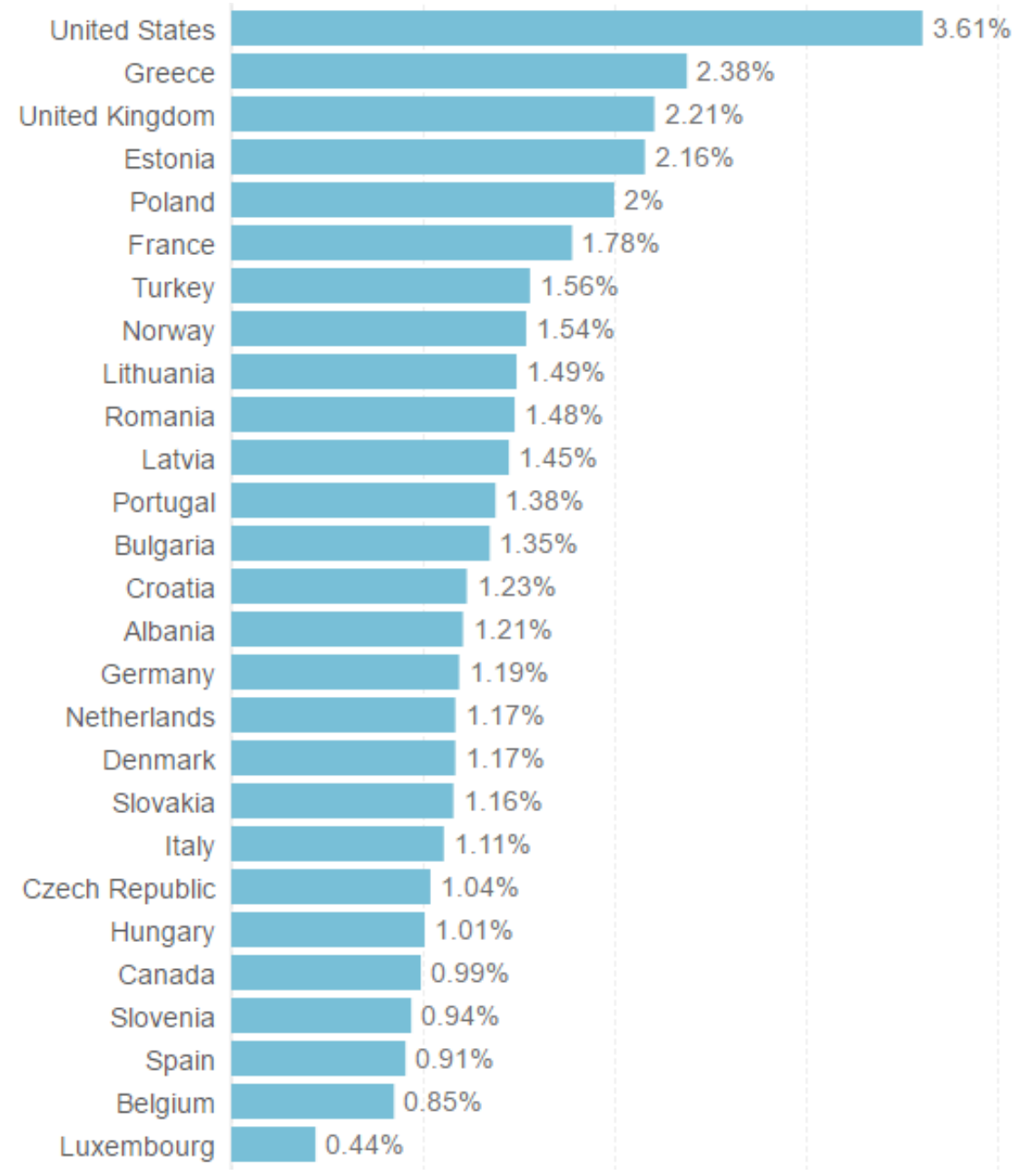

Source: Wright (2016)

It is only Greece, the United Kingdom, Estonia and Poland that spend more than two per cent of their GDP on defence. The effects of the financial crisis deeply affected European defence budgets, which resulted in stressing the 'pooling and sharing' mechanism within the EU (pooling and sharing of military capabilities) and the 'smart defence' agenda within NATO, which was presented by former NATO Secretary General Rasmussen during the NATO summit in Chicago. This multilateral cooperation shows the importance of countries working together and thus increasing efficiency. The approach is not new, but the member countries have still not developed a satisfactory level of trust to be able 
to create more projects based on this agenda. "Defence establishments focusing on maintaining national structures and stepping on the brakes to protect what they have, risk to lose the chance of getting more, and will probably end up with less" (Biscop and Coelmont 2011: 2). Therefore, due to the inability of the European Union to be a more influential player on the security scene, it is obvious that European defence depends on NATO, and the importance of transatlantic ties is also shown in the new European global strategy, where, among other things, it says: "The EU needs to be strengthened as a security community: European security and defence efforts should enable the EU to act autonomously while also contributing to and undertaking actions in cooperation with NATO" (European Union 2016: 20).

The European Union, especially after the Lisbon Treaty, is working on strengthening its defence capabilities under the Common Security and Defence Policy. Without the UK, EU military defence capabilities are reduced, with Germany wondering whether to fully commit to EU common defence and France, on the other side, becomes the only bigger EU member country that has the political will and power to act. However, European defence depends on NATO and is still within NATO. "There is also the EU's relationship with NATO to keep in mind. It has always been a challenge to avoid duplication and inefficiency between the EU and NATO. But the potential for divergence between the two entities could be magnified now that the United Kingdom is no longer around to bridge the breach" (Cilluffo and Cardash 2016). The two organizations share a majority of members and common values, and therefore share the same strategic interests and face the same challenges and threats. The European Union is an essential partner for NATO, and its effort in building its own defence is not taken as a duplication of roles with NATO. European security requires American engagement and presence on European territory.

The former Secretary of State Henry Kissinger may have been right when he told CBS News in December 2016 that Trump's presidency could present an extraordinary opportunity for US foreign policy, especially for US-Europe relations (Kroenig 2017: 2). On the other hand, one hundred days into his presidency, Europe is still struggling to make sense of newly elected American president Donald Trump. There is much consternation and vacillation in European capitals about what the Trump administration's foreign policy will 
entail. Europeans are not sure what Trump's phrase 'America First' means for Europe and the traditional transatlantic relationship.

During the presidential campaign, Donald Trump repeatedly spoke disparagingly of America's allies. Accusing European partners in NATO of not paying enough for defence, Trump even went so far at that time as to entertain the option of pulling back US forces from Europe, even withdrawing the US from NATO and conditioning American security and military protection of Europe, unless European allies fulfil their obligations and increase their defence spending (Brattberg 2017). During his presidential campaign, Donald Trump even called NATO an 'obsolete' organization (Kroenig 2017: 4), but since taking office he has repeatedly voiced his support for the alliance.

The fear that American president Donald Trump would weaken US commitment to NATO has not materialized. Whether coming from President Trump himself, his Vice President Mike Pence at the Munich Security Conference in February 2017, or Secretary of Defence Jim Mattis, the Trump administration has repeatedly offered reassurance that it intends to continue to honour the almost seven-decade long US commitment to the transatlantic partnership and NATO. President Trump has even started to praise NATO's growing defence spending and efforts to boost intelligence sharing and combat terrorism, remarking that NATO is no longer an obsolete organization.

Concerning the European Union, during his presidential campaign Donald Trump showed scepticism about the multilateral institution. He has snubbed an invitation from European Council President Donald Tusk to attend the EU-US summit, advocated the exit of the United Kingdom from the EU and endorsed Eurosceptic candidate Marine Le Pen in the 2017 French presidential election. Despite of all that, Donald Trump has sent a signal that he and his administration are going to cooperate with the EU. During a press conference with the Italian Prime Minister in the White House on 20 April 2017, Trump stated that a strong Europe is very important for him. Also, during his visit to Brussels, Vice President Mike Pence pledged strong American commitment to the European Union. European concerns that Donald Trump would lift some of the sanctions imposed on the Russian Federation after the crisis in Ukraine and Crimea 
have not materialized.

However, the US administration is still sending mixed signals to the European allies, NATO members. Certainly it will take time to reassure and to repair the reservations many Europeans have about Donald Trump and his vision of Europe and the transatlantic relationship in general. The next NATO summit in Brussels in May 2017, and Donald Trump's first visit to Europe during that summit, may be crucial.

\section{Conclusion}

Lots of new challenges and threats are appearing in contemporary international relations - Russian annexation of Crimea, deeper crisis in the Middle East, the threat of the so-called Islamic state - and therefore NATO at the Warsaw Summit renewed its focus on collective defence and deterrence, showing NATO's commitment to Europe but also projecting stability beyond NATO. Warsaw was the last NATO summit for former American President Obama. It is striking how strongly he spoke about the solidarity of the United States with its European allies. In Warsaw, the United States, still with Obama as president, strongly determined to fill the military gaps existing between the country and European members of NATO, which for a decade European members were unable or unwilling to fill. The European Union, especially after the withdrawal of the United Kingdom, with the rise of populism in some European members of NATO and the new approach of new American President Trump towards NATO and its importance, poses a big problem for the unity of NATO. There is a potential danger of a strategic distancing of part of the European continent from the United States. For that reason, a way to preserve a stronger Euro-Atlantic bridge between the United States and the European members of NATO has to be found.

By inviting Montenegro to participate in the Warsaw Summit, the Alliance confirmed that it is on its way to fully-fledged membership. However, little was said about the future of NATO's 'open door' policy. The summit gave 
a cautious nod in the direction of Ukraine and Georgia's aspirations of membership, as well as those of Bosnia and Herzegovina and Macedonia. "Although the military contributions provided by the newest allies are understandably limited, there is sufficient evidence to indicate that expansion had an immediate impact in stabilizing democratic civil-military relations in these new member states. The first positive impact of NATO's expansion is evident in the democratic stability that the enlargement policy helped foster in NATO's newest members" (Hendrickson 2007: 106).

The Warsaw Summit served as a confirmation of NATO's decision to enhance military capabilities, especially on its eastern border, with Russia being active in the international arena again. It is important to stress that it was repeatedly stated in Warsaw that the alliance does not seek any confrontation and poses no threat to Russia if the safety and security of Europe and North America are not endangered.

The main problem is, therefore, whether and how the Warsaw Summit commitments will be implemented in the future. NATO's credibility as a value-based alliance will depend not just on more effective defence spending and other security measures, but also on the quality of the democratic systems of its member states. The main focus is still on outlining NATO's enduring purpose in the new security environment, its influence on European stability and the nature of its fundamental security tasks: collective defence, crisis management and cooperative security. 


\section{B Bibliography}

Andzans, M., 2016. Patching the shield: the Baltic states on the road towards practical NATO guarantees. The Polish Quarterly of International Affairs, 25(1): 13-22.

BBC, 2016. Russia deploys nuclear-capable missiles in Kaliningrad. BBC, [online]. Available at: http://www.bbc.com/news/worldeurope-37597075 (Accessed 27 October 2016).

Bertelsmann Stiftung, 2016. Frayed partnership: German public opinion on Russia. Gutersloh \& Institute for Public Affairs, Warsaw, [pdf]. Available at: http://www.bertelsmann-stiftung.de/fileadmin/files/ user_upload/EZ_Frayed_Partnership_201 6_ENG.pdf (Accessed 27 October 2016).

Biscop, S. and Coelmont, J., 2011 . Pooling and sharing: from slow march to quick march? Egmont Institute Security Policy Brief, No. 23, Egmont, Brussels, [pdf]. Available at: http://www.egmontinstitute.be/ content/uploads/2013/09/SPB23-BiscopCoelmont.pdf?type=pdf (Accessed 2 May 2017).

Brattberg, E., 2017. Lessons for Europe from one hundred days of Trump. [online]. Available at: http://carnegieendowment.org/2017/04/28/ lessons-for-europe-from-one-hundred-days-of-Trump (Accessed 2 May 2017).

Bröning, M., 2016. The rise of populism in Europe: can the center hold? Foreign Affairs, [online]. Available at: https://www.foreignaffairs. com/articles/europe/2016-06-03/rise-populism-europe (Accessed 2 May 2017).

Buras, P. and Balcer, A., 2016. An unpredictable Russia: the impact on Poland. European Council on Foreign Relations, 15 July [online]. Available at: http://www.ecfr.eu/article/commentary_an_ unpredictable_russia_the_impact_on_poland (Accessed 27 October 2016).

Champion, M., 2016. NATO has bigger problems than Brexit as German 
ambivalence rears. Bloomberg, 8 July [online]. Available at: http:// www.bloomberg.com/news/articles/2016-07-08/nato-has-biggerproblems-than-brexit-as-german-ambivalence-rears (Accessed 27 October 2016).

Chance, M., 2016. Russia's military might: Putin's foreign policy in numbers. CNN, [online]. Available at: http://edition.cnn.com/2016/05/11/ europe/russia-military-putin-foreign-policy/ (Accessed 27 October 2016).

Cilluffo, F. J. and Cardash, S. L., 2016. NATO after Brexit: Will security cooperation work?. Foreign Affairs, 4 July [online]. https://www. foreignaffairs.com/articles/united-kingdom/2016-07-04/nato-afterbrexit (Accessed 27 October 2016).

Corvaja, A. S., 2016. Beyond deterrence: NATO's agenda after Warsaw: prospects for German foreign policy. Berlin: Konrad Adenaver Stiftung.

Čehulić Vukadinović, L., 2010. Euroatlantizam i suvremeni međunarodni odnosi. Zagreb, Podgorica: Politička Kultura, CID.

De Luce, D. and McLeary, P., 2016. Brexit is good news for Russia, but a headache for NATO. Foreign Policy, 26 June [online]. Available at: http://foreignpolicy.com/2016/06/26/brexit-is-good-news-forrussia-but-a-headache-for-nato/ (Accessed 27 October 2016).

Edström, H., Matlary, J. H. and Petersson, M., 2011 . Utility for NATO: utility of NATO?, pp.1-17. In: Edström, H., Matlary, J. and Petersson, M. eds. NATO: The Power of Partnerships. Palgrave Macmillan.

European Union, 2003. A security Europe in a better world. European Security Strategy. [online]. Available at: https://europa.eu/ globalstrategy/en/european-security-strategy-secure-europebetter-world (Accessed 27 October 2016).

European Union, 2016. A global strategy for the European Union's foreign and security policy: shared vision, common action: a stronger Europe. [pdf]. Available at: https://europa.eu/globalstrategy/sites/ globalstrategy/files/eugs_review_web.pdf (Accessed 27 October 2016). 
Fata, D., 2011 . Europe in transition: from what to where?. In: Maior, G. C. and Konoplyov, S. eds. Strategic Knowledge in the Wider Black Sea Area. Bukurest: Editura Rao. pp. 33-39.

'Frayed Partnership' German public opinion on Russia, 2016. Bertelsmann Stiftung and Institute of Public Affairs in Warsaw, [pdf]. Available at: https://www.bertelsmann-stiftung.de/fileadmin/files/user_upload/ EZ_Frayed_Partnership_2016_ENG.pdf (Accessed 27 October 2016).

Gerasimov, V., 2013. The value of science is in the foresight: new challenges demand rethinking the forms and methods of carrying combat operations. Military Industrial Courier, 27 February [pdf]. Available at: http://vpk-news.ru/sites/default/files/pdf/VPK_08_476. pdf (Accessed 12 June 2015).

Goodwin, M., 2011 . Right response: understanding and countering populist extremism in Europe. Chatham House Report, 1 September [online]. Available at: https://www.chathamhouse.org/publications/ papers/view/178301 (Accessed 12 June 2016).

Hegedus, D., 2016. The Kremlin's influence in Hungary: are Russian vested interests wearing Hungarian national colors? DGAP Kompakt, 8(1): $1-11$.

Hendrickson, R. C., 2007. The miscalculation of NATO's death. Parameters: U.S. Army War College, 37(1): 98.

Henley, J., Bengtsson, H. and Barr, C., 2016. Across Europe, distrust of mainstream political parties is on the rise. The Guardian, 25 May [online]. Available at: https://www.theguardian.com/world/2016/ may/25/across-europe-distrust-of-mainstream-political-parties-ison-the-rise (Accessed 27 October 2016).

Hill, F. and Gaddy, C. G., 2013. Mr. Putin: operative in Kremlin. Washington DC: Brookings Institution Press.

Kacprzyk, A., 2016. Revisionist Russia. In: Terlikowski, M. ed. NATO and the future of peace in Europe: towards a tailored approach. Warsaw: The Polish Institute of International Affairs. pp. 9-12.

Körber Stiftung, 2016. Russia in Europe: rapprochement or isolation. Forum for Impulse, [pdf]. Available at: https://www.koerber- 
stiftung.de/fileadmin/user_upload/internationale-verstaendigung/ fokus_russland-in-europa/pdf/2016/Survey_Russia-in-Europe.pdf (Accessed 27 October 2016).

Körber Stiftung Survey, 2016. Russia and Europe: rapprochement or isolation?. [online]. Available at: https://www.koerber-stiftung. de/en/news-archive/news-archive-details/russia-and-europerapprochement-or-isolation-833.html (Accessed 27 October 2016).

Kroenig, M. 2017. The case for Trump's foreign policy. The right people, the right positions. Foreign Affairs, [online]. Available at: https://www. foreignaffiars.com/artcles/world/2017-04-17/case-trump's-foreignpolicy (Accessed 2 May 2017).

Lorenz, W., 2016. NATO at a critical crossroads. The Polish Quarterly of International Affairs, 25(1): 9-13.

Luciolli, F., 2016. NATO in 3D: deterrence, defence and dialogue. In: Strengthening peace and security. NATO summit 2016. Brussels: The Atlantic Treaty Association. p. 21.

Miller, P. D., 2016. How World War II could begin in Latvia. Foreign Policy, 16 November [online]. Available at: http://foreignpolicy. com/2016/11/16/how-world-war-iii-could-begin-in-latvia/ (Accessed 20 November 2016).

NATO, 2016a. Defence expenditures of NATO countries. [online]. Available at: http://www.nato.int/cps/en/natohq/news_127537. htm (Accessed 27 October 2016).

NATO, 2016b. Joint declaration by the President of the European Council, the President of the European Commission and the Secretary General of the North Atlantic Treaty Organization. NATO Press Release, 19, 8 July [online]. Available at: http://www.nato.int/cps/ en/natohq/ offical_text_133163.htm (Accessed 21 July 2016).

Parfitt, T., Philp, C., Waterfield, B. and Savage, M., 2016. Putin moves his missiles in the threat to Europe. The Times, 22 November [online]. Available at: http://wnw.thetimes.co.uk/article/putin-moves-his-missilesin-new-threat-to-europe-fbapr9m9g (Accessed 27 November 2016).

Posener, A., 2016. German nationalism can only be contained by united 
Europe. The Guardian, 20 June [online]. Available at: https:// www.theguardian.com/commentisfree/2016/jun/20/germannationalism-contained-united-europe-brexit-alternative-furdeutschland (Accessed 27 October 2016).

Public Diplomacy Division, 2016. Warsaw summit key decisions. North Atlantic Treaty Organization, [pdf]. Available at: http://www. nato.int/nato_static_fl2014/assets/pdf/pdf_2016_09/20160906 _1609-factsheet-warsaw-summit-key.pdf (Accessed 27 October 2016).

Reuters, 2016. Baltics, fearing Russia, to triple military spending by 2018 : report. Reuters, [online]. Available at: http://www.reuters.com/ article/Us-baltics-military-idUSKCN12J2S4 (Accessed 27 October 2016).

Rynning, S., 2002. Autonomous defence? The role of military forces in EU external affairs. Copenhagen Peace Research Institute (COPRI), National Europe Centre Paper No.17.

Shukla, S. and Smith-Spark, L., 2016. Russia unveils 'Satan 2' missile, could wipe out France or Texas. CNN, [online]. Available at: http://edition. cnn.com/2016/10/26/europe/russia-nuclear-missile-satan-2/ (Accessed 27 October 2016).

Sloan, S. R., 2016. NATO's Warsaw summit. Rearranging deckchairs on the Titanic. Atlantisch Perspectief, 3: 4-23.

Snyder, G. H., 1984. The security dilemma in alliance politics. World Politics, 36(4): 461-495.

Snyder, G. H., 1990. Alliance theory: a neorealist first cut. Journal of International Affairs, 44(1): 103-123.

Snyder, G. H., 1997. Alliance politics. Ithaca, NY: Cornell University Press.

Stanek, H., 2016. Is Russia's alliance with Greece a threat to NATO? National Interest, [online]. Available at: http://nationalinterest.org/ feature/russias-alliance-greece-threat-nato-16998 (Accessed 27 October 2016).

Stoltenberg, J., 2016. Now is not the time for the US to abandon NATO - nor should its European allies go it alone. The Guardian, 12 
November [online]. Available at: https://www.theguardian.com/ commentisfree/2016/nov/12/us-must-not-abandon-nato-europego-alone-jens-stoltenberg (Accessed 27 November 2016).

Turner, M. R. 2016. Deterring to defend: delivering on NATO's promise. Brussels: NATO Parliamentary Assembly.

Walt, S. M., 1985. Alliance formation and the balance of world power. International Security, 9(4): 3-43.

Walt, S. M., 1997. The origin of alliances. Ithaca, NY: Cornell University Press Walt, S. M., 2000. NATO's future (In Theory). In: Martin, P. and Brawley, M. R. eds. Alliance politics, Kosovo and NATO's war: allied force or forced allies?. New York: Palgrave. pp. 11-26.

Walt, S. M., 2004. The imbalance of power: on the prospects for effective American-European relations. Harvard Magazine, MarchApril,[online]. Available at: http://harvardmagazine.com/2004/03/ the-imbalance-of-power.html (Accessed 1 May 2017).

Waltz, K. N., 1979. Theory of international politics. Reading MA: AddisonWesley.

Waltz, K. N., 1993. The emerging structure of international politics. International Security, 18(2): 44-79.

Waltz, K. N., 2000. Structural realism after the Cold War. International Security, 25(1): 5-41.

Wright, B., 2016. What is NATO? Donald Trump threatens to leave North Atlantic Treaty Organization. Military alliance as Russia ties questioned. International Business Times, 11 October [online]. Available at: http://www.ibtimes.com/what-nato-donald-trumpthreatens-leave-north-atlantic-treaty-organization-military-2444950 (Accessed 27 October 2016). 
Lidija Čehulić Vukadinović (radovanvukadinovic@hotmail. com), PhD, is a Professor of International Relations, International Organizations and Euro-Atlantic Organizations at the Faculty of Political Science, University of Zagreb, Croatia. Prof. Čehulić has published numerous books and articles, works as editor of scientific publications, and has participated in different scientific conferences and seminars in Croatia and abroad. Prof. Čehulić is also active in the non-governmental sector and is a member or board member of several associations such as the Atlantic Council of Croatia, the Centre for International Studies, the Croatian Association for International Studies and International Studies Association (ISA). In her books, prof. Čehulić pursues Euro-Atlanticism as a form of transatlantic relations.

Monika Begović (monika.begovic@gmail.com) holds a PhD in Political Science. Begović is active in researching transatlantic relations, especially from the perspective of international security, as well as studying the influence of Euro-Atlantic values on South-Eastern Europe. During research projects, Begovic is advancing the field of scientific research, and has published numerous essays and papers, and participates at international scientific conferences, with a special interest in the Western Balkan countries. During her professional career, Begović has specialized in project management, worked with the United Nations, managed EU projects and is active as a consultant in the NGO sector. Begovic is Vice-President of the think-tank Centre for International Studies and the Atlantic Council of Croatia.

Luka Jušić (lukajusic@gmail.com), BA, is a Master's student at the Faculty of Political Science at the University of Zagreb. He focuses on the fields of international relations, national, regional and international security, politics of history and political economy. Jušić is an active student and is also a member of the Atlantic Council of Croatia and several other national and international organizations. 